\section{Ks. Dariusz Kotecki}

Uniwersytet Mikołaja Kopernika w Toruniu dkotecki@umk.pl

DOI: http://dx.doi.org/10.12775/BPTh.2016.033

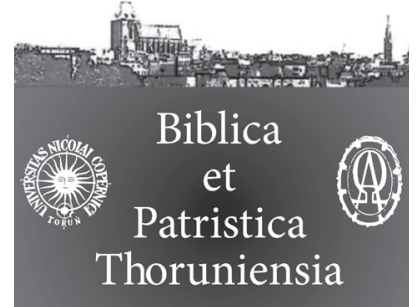

9 (2016) 4: 29-53

ISSN (print) 1689-5150

ISSN (online) 2450-7059

\title{
"Słowo stało się ciałem". Teologia i historia w J 1,14: klucz do chrystologii
}

\author{
"And the Word became flesh". Theology \\ and History in John 1:14: key to Christology
}

Streszczenie. Autor artykułu, analizując zdanie z J 1,14: „A Słowo stało się ciałem i zamieszkało między nami, i oglądaliśmy Jego chwałę, chwałę, jaką jednorodzony [ma] od Ojca, pełnia laski i prawdy", dochodzi do wniosku, że w wierszu tym krzyżują się ze sobą w spojrzeniu na tajemnicę Jezusa Chrystusa perspektywa teologiczna i historyczna. Ewangelista proponuje w J 1,14 równowagę między tym, co dzisiaj nazywa się chrystologią odgórną (wysoką lub boską), a oddolną (niską) poprzez wskazanie, że chrystologia nie może być jednostronnie historyczna, czy jednostronnie teologiczna, że chrystologia jest zakorzeniona w Pismach Żydów - w Starym Testamencie, który zawiera chrystologię ukrytą („starotestamentalne zbliżenia do wcielenia”) pozwalającą odkryć, że sam Chrystus jest Teologią.

\begin{abstract}
The author of article analyzing the sentence from John 1:14: "And the Word became flesh and dwelt among us, and we saw his glory, the glory which only begotten [is] of the Father, full of grace and truth" comes to the conclusion that in this verse intersect together theological and historical perspective in looking at the mystery of Jesus Christ. Evangelist proposes balance between what today is called Christology from above (high or divine Christology) and bottom-up (low Christology), by showing that Christology can not be unilaterally theological or unilaterally historical. That Christology is rooted in the Scriptures of the Jews - in the Old Testament, which contains a hidden Christology (Old Testament approximation of the Incarnation) and allows to discover that Christ himself is Theology.
\end{abstract}

Słowa kluczowe: J 1,1-2.14; wcielenie Jezusa; chrystologia; perspektywa teologiczno-historyczna.

Keywords: John 1,1-2.14; the incarnation of Jesus; Christology; theological and historical perspective. 
Drolog do Ewangelii wg św. Jana $(1,1-18)$ należy do jednego z najbardziej studiowanych tekstów z Nowego Testamentu ${ }^{1}$. Jego analiza nie doprowadziła badaczy do jednoznacznych wniosków, co do gatunku literackiego (hymn czy Psalm do Logosu); odpowiedzi na pytanie, które jego części należały do pierwotnego hymnu, a które są późniejszym dodatkiem ${ }^{2}$. W artykule tym te kwestie jednak nas nie interesują. Wystarczy powiedzieć, że uznajemy za wieloma badaczami, iż pierwotny hymn - poza dwoma fragmentami o Janie Chrzcicielu (1,6-8.15) - odpowiada obecnemu Prologowi. Punktem szczytowym Prologu jest J 1,14: „A Słowo stało się ciałem i zamieszkało między nami, i oglądaliśmy Jego chwałę, chwałę, jaką jednorodzony ma od Ojca, pełen łaski i prawdy”. Martin Hengel podkreśla ważność J 1,14 dla całej Czwartej Ewangelii: „Szczytem i celem jest wcielenie Słowa w w. 14. To jest klucz do dwudziestu jeden rozdziałów, które potem następują"3. Wiersz czternasty oraz pierwszy są dwoma miejscami w Prologu, w których autor używa terminu logos („Słowo”). Te dwa wiersze stanowią inkluzję i są kluczowe dla zrozumienia całego prologu, który dla $\mathrm{H}$. Thyena stanowi: „wskazanie dla czytelnika, jak powinna być czytana i rozumiana cała Ewangelia” ${ }^{4}$, a dla M. Hengla jest „bramą wejściową dla chrystologicznej prawdy" ${ }^{5}$. Z tym stwierdzeniami trudno polemizować, chociażby na podstawie faktu, że wiele kluczowych terminów dla Czwartej Ewangelii są wprowadzone właśnie w Prologu ${ }^{6}$. W pierwszych dwóch wierszach Prologu, których głównym protagonistą jest logos, orzeczenia są w formie imperfectum, $\mathrm{w}$ wierszu czternastym natomiast są w formie aorystu, który wskazuje na konkretne wydarzenie $z$ historii. Jednocześnie wiersz pierwszy i czternasty są jedynymi, w których w całym Prologu spotyka się termin logos. Te dwa wiersze stanowią inkluzję. Użycie tego terminu - niosącego w sobie ogromny ładunek teologiczny - w w. 1,14, w którym zostaje tak mocno zaakcentowana perspektywa historyczna, pozwala na wysunięcie wniosku, że w wierszu tym teologia i historia krzyżują się ze sobą i wzajemnie się dopełniają. Można zatem mówić o perspektywie teologiczno-historycznej, która powinna znaleźć swoje potwier-

\footnotetext{
1 Por. bibliografia zebrana w: S. Mędala, Ewangelia wedtug świętego Jana, s. 285-286.

2 Zob. H. Witczyk, Kościół Syna Bożego, s. 59-89.

3 M. Hengel, The Prologue of the Gospel of John, s. 268.

4 H. Thyen, Aus der Literatur zum Johannesevangelium, s. 223 (całość 53-69; 222-

5 M. Hengel, The Prologue of the Gospel of John, s. 273-294.

6 Do takich terminów należą: „życie” (zōē): 1,5.9; ciemność (skotia): 1,5; świat (kosmos): 1,9; swoja własność (idia): 1,11; dzieci Boga (tekna theou): 1,12; ciało (sarks): 1,14; chwałą (doksa): 1,14; ,jednorodzony” (monogenous, monogenēs): 1,14.18); „od Ojca” (para
} -252). patros): 1,14 . 
dzenie w dokładnej analizie J 1,14. Celem niniejszego artkułu jest ukazanie tej perspektywy na podstawie analizy J 1,14. Ta perspektywa ma wielkie znaczenie nie tylko dla chrystologii Janowej, lecz także jest fundamentalną przesłanką dla całej chrystologii. Aby osiągnąć zamierzony cel, zanim przystąpimy do analizy słów z J 1,14 (paragraf 2), dokonamy analizy pierwszych wierszy Prologu, które bezpośrednio mówią o Słowie (paragraf 1), aby na końcu wyciągnąć wnioski, które wydają się fundamentalne dla chrystologii (paragraf 3).

\section{Logos w odwieczności Boga (J 1,1-2)}

Pierwsza strofa Prologu brzmi: „Na początku było Słowo, a Słowo było ukierunkowane na Boga i Bogiem było Słowo. Ono było na początku ukierunkowane na Boga”. Należy pamiętać - jak zauważa S. Mędala - „że grecki wyraz logos ma szersze znaczenie niż polskie słowo lub łacińskie verbum. Logos oznacza pierwotnie słowo, ale nie słowo-dźwięk, nie słowo-formę gramatyczną, lecz ra-

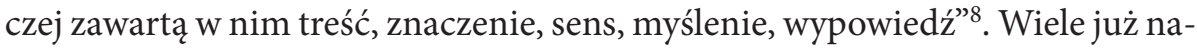
pisano na temat, z jakiego środowiska kulturowo-literackiego mógłby pochodzić tytuł $\operatorname{Logos}^{9}$. Słusznie zauważa M. Hengel, że odpowiednikiem greckiego słowa logos jest hebrajski rzeczownik dābār czy aramejski memrā, które wyrażają rzeczywistość proklamowania stwórczej potęgi Boga i Jego pełnej miłości woli w połączeniu z boskim imieniem (shem), które opisuje Boga jako osobę ${ }^{10}$. Nie można na pewno tego pojęcia oderwać od tradycji biblijnych, zwłaszcza tradycji sapiencjalnej, gdzie przywołuje się uosobioną postać Mądrości Bożej (Prz 8,22-31; Hi 28; Syr 24; Mdr 6-9; por. Ba 3,9-4,4) ${ }^{11}$, chociaż należy pamiętać, że nigdzie $\mathrm{w}$ tych tekstach nie pojawia się utożsamienie Mądrości $\mathrm{z}$ istotą Boską, jak to ma miejsce w przypadku Logosu, czy też utożsamienie Mądrości (sophia) z samym Logosem, co z kolei można odnaleźć w pismach Filona z Aleksandrii ${ }^{12}$. Według mnie można mówić o charakterze przygotowawczym

7 Komentatorzy różnią się między sobą, które wiersze przyjąć za pierwszą strofę. Zazwyczaj padają dwie propozycje: ww. 1-2 lub ww. 1-3. Pierwsza propozycja wydaje się właściwsza, ponieważ opisuje bycia Słowa, od w. 3 mamy opis Słowa w działaniu.

8 S. Mędala, Ewangelia według świętego Jana, s. 257.

9 Jako swoistego rodzaju podsumowanie całej dyskusji na ten temat zob. S. Mędala, Ewangelia według świętego Jana, s. 243-247; H. Witczyk, Kościół Syna Bożego, s. 23-58.

10 M. Hengel, The Prologue of the Gospel of John, s. 273.

11 Zob. G. Rochais, La Formation du Prologue (Jn 1:1-18), s. 5-44.

12 Zob. T. Tobin, The Prologue of John and Hellenistic Jewish Speculation, s. 252-269: autor zauważa, że pierwszym autorem, który utożsamia Mądrość ze Słowem oraz nadaje mu boskiego charakteru jest Filon z Aleksandrii. 
tekstów starotestamentalnych do koncepcji Logosu, prezentowanego przez Jana. Stwierdzenie jednak bezpośredniej zależności od konkretnych tekstów czy tradycji pozostaje w sferze hipotez ${ }^{13}$.

Logos Janowy jest od samego początku ukazany jako osoba. „W całym Nowym Testamencie nie ma tekstu, który w równie doskonały i precyzyjny sposób ukazywałby Jezusa Chrystusa jako osobę odwiecznego Słowa - Logosu, Jednorodzonego Syna Bożego” "14. Całe zdanie: „Na początku było Słowo, a Słowo było ukierunkowane na Boga", które przez obecność wyrażenia en archē przywołuje początek z Rdz 1,1, nie odnosi się do dzieła stworzenia (o nim będzie mowa dopiero w wierszu trzecim), wbrew tym poglądom, które chciały widzieć w Logosie pierwsze stworzenie, chociażby wspomnieć w tym miejscu arianizm, ale do okresu przed stworzeniem i należy je interpretować jako opisujące odwieczne bycie Logosu w odwieczności Boga (przed jakimkolwiek czasem), w nierozerwalnej wspólnocie z Nim. Na trwającą w odwieczności Boga egzystencję Logosu wskazuje wyraźnie „imperfectum” èn w wyrażeniu en archē èn ho logos („Na początku było słowo”), które kontrastuje wyraźnie $\mathrm{z}$ „aorystem” egeneto („stało się”) w w.3, odnoszącym się do dzieła stworzenia (panta diautou egeneto, „wszystko przez Nie stało się"). Egzystencja Słowa jest całkowicie niezależna od stworzenia, jest ponad czasem, innymi słowy, jest odwieczna. Jednocześnie to Słowo jest od zawsze ukierunkowane na Boga (ēn pros ton theon $)^{15}$. Ewangelista przenosi czytelnika i słuchacza Ewangelii na płaszczyznę transcendencji Boga, gdzie istnieje tylko osobowy związek, relacja między Słowem i Bogiem. Logos jest ukierunkowany na Boga i jednocześnie jest Bogiem (kai theos èn ho logos, „i Bogiem było Słowo”). Nie może być żadnej wątpliwości, co do boskiej tożsamości Słowa. Ewangelista nie mówi o boskim charakterze słowa, ale o istnieniu właściwym dla Boga (ta sama natura), przy zachowaniu odrębności osób (Słowo nie jest Bogiem Ojcem $)^{16}$. Ukierunkowanie na Boga, wskazuje na wzajemną miłość między Słowem a Bogiem, która później w teologii spekulatywnej jest

13 Por. U.C. van Wahlde, The Gospel and Letters of John, v. 2: Commentary on the Gospel of John, s. 26.

14 H. Witczyk, Kościół Syna Bożego, s. 21.

15 Badacze różnie tłumaczą przyimek pros. Jedni odwołują się do jego znaczenia w grece klasycznej lub koine, inni w LXX, pod wpływem tekstu hebrajskiego, jeszcze inni do jego specyficznego znaczenia w języku Jana. Najbardziej słuszna wydaje się propozycja, która uwzględnia kontekst Ewangelii, gdzie Ewangelista znajduje się na linii użycia klasycznego przyimka, tj. wskazywania na kierunek, stąd najlepszym tłumaczeniem byłoby „ukierunkowane ku, skierowane ku".

16 Opis egzystencji logosu nie jest skonstruowany za pomocą terminologii używanej w orzeczeniach dogmatycznych. Oczywiście narracja Janowa wyraża to samo, co potem zostaje określone w Credo nicejskim: „Bóg prawdziwy z Boga prawdziwego, zrodzony nie 
nikim innym jak Duchem Świętym. Ta sama myśl zostanie wyrażona w J 17,24, gdzie Jezus mówi o miłości Boga Ojca do siebie; „przed założeniem świata” (przed stworzeniem). J 1,1 koresponduje $\mathrm{z}$ tym, co zostanie wypowiedziane w 10,30: „Ja i Ojciec jedno jesteśmy”. Jezus jest z Ojcem, ale nie jest identyczny z Nim. W J 1,1 autor, patrząc na słowo z perspektywy czasowej (w wieczności), z perspektywy relacji do Boga (ukierunkowane na Boga, zwrócone do Boga), i z perspektywy jakości (było Bogiem), podkreśla transcendencję Słowa i Jego dystans od świata stworzonego (materialnego): „Świat - jak zauważa S. Mędala - ma początek, Słowo już jest na początku, a więc przed wszelkim stworzeniem; świat obejmuje całość przestrzenno-czasową, Słowo znajduje się poza nią, w odniesieniu do Boga, należy do sfery Bożej; pojęcie świata rodzi pytanie o istnienie (wszystko albo nic), Słowo jest kimś - Bogiem"17.

Mówiąc o Logosie nie sposób nie zapytać o to, dlaczego Ewangelista wybrał takie określenie, na ukazanie tożsamości Jezusa. Podstawową funkcją słowa jest komunikacja. Jezus jest nazywany Logosem, ponieważ jest przeznaczony do mówienia do ludzi. Owo mówienie do ludzi nie obejmuje tylko słów, ale także działania czy czyny (wydarzenia), które są wewnętrznie ze sobą powiązane, jak to nam przypomina - mówiąc o objawieniu - Konstytucja o Objawieniu Bożym Dei Verbum (KO 2), a co zgadza się z całą koncepcją starotestamentalną słowa dabar.

Od w. 3 autor mówi o przejawach działania Słowa. W 1,3 mamy wyraźne odwołanie się do dzieła stworzenia: „Wszystko przez nie [Słowo] stało się, a bez niego nic się nie stało". Całe dzieło stworzenia jest traktowane jako pierwszy akt objawienia Boga, ono jest widziane jako wydarzenie, wraz z którym świat i jego historia się rozpoczynają (stąd mamy orzeczenie egeneto $)^{18}$. Zatem pod słowem „wszystko” (panta) nie kryje się tylko stworzenie pojedynczych rzeczy, ale także historia, w tym historia zbawienia. W Czwartej Ewangelii słowo panta bez rodzajnika - tak jak mamy w 1,3 - odnosi się do dzieła Chrystusa (3,35; $5,20 ; 17,10 ; 19,28)$, w kontekście Jego działalności objawicielskiej i zbawczej, co więcej, konstrukcja zdania panta diautou egeneto przypomina tę z J 1,17, gdzie łaska i prawda stały się przez Jezusa (hē charis kai hē alētheia dia Iēsou Christou egeneto $)^{19}$. Kontekst Ewangelii, jak i paralelizm między ww. 3 i 17 pozwala spojrzeć na 1,3 nie tylko w kontekście stworzenia, lecz także całego objawienia. W całym tym dziele Logos jest mediatorem, na co wskazuje Janowe użycie

stworzony, współistotny Ojcu" (zob. Breviarium Fidei. Wybór doktrynalnych wypowiedzi Kościoła, s. 611-612).

17 S. Mędala, Ewangelia wedtug świętego Jana, s. 258.

18 Por. M. Hengel, The Prologue of the Gospel of John, s. 273.

19 Por. H. Witczyk, Kościół Syna Bożego, s. 109. 
przyimka dia. Ono współdziała z Bogiem w „stawaniu się" historii i objawienia. Inspiracją do takiego spojrzenia na dzieło objawienia i stworzenia mogły być dla Jana Ps 33, w którym stwierdza się: „Przez słowo Pana [LXX: tō logō kyriou] powstały niebiosa i wszystkie ich zastępy przez tchnienie ust Jego” $(33,6)$; „Bo on przemówił, a powstało [LXX: autos eipen, kai egenèthēsa], On rozkazał, a zaczęło istnieć" (33,9), czy Mdr 9,1, gdzie słowo i mądrość Boga są tożsame ze sobą i biorą udział w stworzeniu („Boże przodków i Panie miłosierdzia, któryś wszystko uczynił sowim słowem [LXX: ho poiēsas ta panta en logō sou] i w mądrości swojej stworzyłeś człowieka [kai tē sophia sou kataskeuasas anthrōpon], czy Syr 24, w którym to tekście mądrość, słowa stworzenia i Tora stają się wyrazicielami działania Boga i Jego objawienia ${ }^{20}$.

W J 1,1 orzeczenie e en , jak to wynika $\mathrm{z}$ kontrastu $\mathrm{z}$ aorystem egeneto $\mathrm{w} 1,3$, wskazuje na odwieczne bycie Logosu z Bogiem. Autor wyraźnie zaznacza ten kontrast i wydaje się, że staje się on paradygmatyczny dla pozostałych strof Prologu (i tym samym dla ich interpretacji), w których zostaje ukazany także ten kontrast. Można założyć za wieloma komentatorami, że w miejscach Prologu, gdzie występuje orzeczenie èn podmiotem jest Logos. Orzeczenie èn znika całkowicie po 1,10. W 1,11 po raz pierwszy w Prologu mamy w orzeczeniu, którego podmiotem jest Słowo określane jako światło, aoryst èlthen („przyszło”) w zdaniu: „przyszło do swojej własności i swoi go nie przyjęli”. Pytaniem otwartym pozostaje kwestia, czy w 1,10-12 mówi się już o Słowie Wcielonym w misterium Jezusa Chrystusa (Brown, Simoens, Mędala) czy też o aktywności Słowa w czasach Starego Testamentu (Westcott, Bernard, Boismard, Schnackenburg, Hengel)? Dlaczego autor Prologu nie mówi wprost o wcieleniu? Nie przekonuje mnie argumentacja S. Simoensa, który podkreśla, że chodziłoby o to, aby wcielenie jak w najwyższym stopniu umieścić w stwórczym i zbawczym zamyśle Boga. Nie mówi się zatem bezpośrednio o wcieleniu, aby rozszerzyć do granic możliwości horyzont Jego wcielenia ${ }^{21}$. Nie ulega wątpliwości, że w. 14, mówiąc bezpośrednio o wcieleniu, uwypukla nowy etap bycia Słowa. Stąd można założyć, że w. 1-13 odnoszą się do odwiecznego bycia Słowa, skierowanego ku Bogu (transcendencja Słowa), które jest widziane jednak w relacji ze światem (immanencja Słowa ${ }^{22}$. Ta relacja ze światem jest ukazana najpierw w motywie

20 R.E. Brown, Giovanni, s. 1467-1471; M. Hengel, Studies in Early Christology, s. 101n.; C.S. Keener, Komentarz historyczno-kulturowy do Nowego Testamentu, s. 187.

21 Y. Simoens, Secondo Giovanni, s. 132.

22 Zob. M. Hengel, The Prologue of the Gospel of John, s. 272-289: autor dzieli Prolog na dwie części: „Prehistorię (ww. 1-13)”, którą w odniesieniu do Logosu nazywa „Logos asarkos” („Logos niecielesny”) oraz na „Wcielenie (ww. 14-18)”, które określa jako „Logos ensarkos” („Logos wcielony”). 
stworzenia, potem zaś w motywie wchodzenia słowa w kontakt z ludźmi, który można określić w kategoriach objawienia. W całym Starym Testamencie wyróżnia się dwie grupy tekstów w odniesieniu do słowa Boga. Pierwsza z nich prezentuje słowo Boga jako siłę stwórczą, czego znakomite przykłady znajdujemy w Rdz 1,2.3 czy Ps 33,6.9. W drugiej grupie tekstów słowo Boga jest ukazane jako komunikacja, objawienie (por. Jr 1,4; Ez 1,3; Am 3,1). Jan w Prologu doprecyzowuje to wszystko, co o roli słowa Boga mówił Stary Testament (mediacyjna funkcja hokmah/sophia w stworzeniu), nadając słowu charakteru osobowego Logosu, którego tożsamość zostanie odkryta bezpośrednio na końcu Prologu, gdzie po raz pierwszy padnie imię Jezusa Chrystusa $(1,18)$. To, co było do końca nieodkryte, staje się jawne w Jezusie Chrystusie - Słowie. Dla Jana stworzenie jest pierwszym wejście Słowa w świat, w którym krzyżują się ze sobą wydarzenie (stworzenie) i objawienie (komunikacja). Jan reinterpretuje chrystologicznie całe dzieło stworzenia. W stworzeniu Bóg wyraża samego siebie, ale czyni to przez Logos, który przynależy do świata Boga, jest z Nim całkowicie złączony, chociaż stanowi odrębną osobę. Taki koncept wpisuje się w to, co mówią o Chrystusie pierwsze wiersze Listu do Hebrajczyków, gdzie podkreśla się, że Chrystus jest „odblaskiem Jego [Boga] chwały i odbiciem Jego istoty” $(1,3)$ i jako taki jest mediatorem stworzenia („przez Niego stworzył [Bóg] światy”: 1,2). Jan w Prologu doprecyzowuje to, co Stary Testament tylko przeczuwał. Od momentu stworzenia rozpoczyna się udział Słowa w całej historii Starego Testamentu. Wiersze 4-5.9-13 opisują - według mnie - to wszystko, co w ST było „zbliżeniami do wcielenia Boga"23. Można mówić w tym miejscu o starotestamentalnej chrystologii ukrytej. Cały ST mówi o komunikowaniu się Boga przez słowo i wydarzenia. Są one ilustracją tego, o czym mówi autor Listu do Hebrajczyków: „Wielokrotnie i na różne sposoby przemawiał Bóg niegdyś do ojców przez proroków" (Hbr 1,1). Wydaje mi się, że to jest właściwy klucz do interpretacji wierszy 4-13, chociaż muszę przyznać, że pozostaje po przyjęciu takiego klucza problematyczną interpretacja w. 12, który dla R.E. Browna jest potwierdzeniem widzenia w w. 10-12 odniesienia do wcielenia Słowa ${ }^{24}$. Jest to jednak temat do nowego artykułu. Po tych analizach możemy przystąpić do egzegezy J 1,14.

23 Określenie to zaczerpnąłem z Ch. Schönborn, Bóg zesłał Syna Swego. Chrystologia, s. 113.

24 R.E. Brown, Giovanni, s. 41. 


\section{Logos Wcielony (J 1,14)}

Wiersz, który jest przedmiotem niniejszego artkułu, brzmi: kai ho logos sarks egeneto kai eskēnōsen en hymin kai etheasametha tèn doksa autou, doksan ōs monogenous para patros plērēs charitos kai alētheias („A Słowo ciałem się stało i zamieszkało między nami i oglądaliśmy Jego chwałę, chwałę jaką jednorodzony od Ojca [ma], pełnia łaski i prawdy".

\section{1. „A Słowo stało się ciałem”}

J 1,14 poprzez użycie terminu logos bezpośrednio nawiązuje do J 1,1-2: kai ho logos sarks egeneto („A Słowo stało się ciałem”). Cały Prolog rozwija się zatem wokół terminu logos. „Słowo”, które jest widziane jako życie i światłość prawdziwa $(1,4.9)$, staje się sarks („ciało”) i to w konkretnym człowieku, Jezusie Chrystusie $(1,18)$. Konkretny człowiek zajmuje miejsce Logosu. W Nim, w galilejskim Żydzie Słowo staje się ciałem ${ }^{25}$.

Sam termin sarks wskazuje na to, co kruche, przemijające, to człowiek widziany od strony zewnętrznej, materialnej, w tym wszystkim, co ostatecznie podlega śmierci. W jasny sposób wyraża tę prawdę Iz 40,6 (LXX): „Wszelkie ciało [pasa sarks] to jakby trawa, a cały wdzięk człowieka [doksa anthrōpou] jak kwiat polny". Termin sarks odpowiada hebrajskiemu pojęciu bāśār, które w Starym Testamencie wskazuje na solidarność między istotami ożywionymi, w odniesieniu do człowieka pozwala go widzieć jako element świata widzialnego, w końcu w relacji do Boga, każe patrzeć na ciało jako na coś całkowicie różnego od $\mathrm{Boga}^{26}$. Słowo staje się zatem czymś ze świata. Staje się zmysłowe, ograniczone, fizyczne i przemijalne.

Kontekst Czwartej Ewangelii może nas poprowadzić do odkrycia jeszcze większej głębi zdania: „A Słowo stało się ciałem”. Słowo sarks występuję w J w trzech różnych znaczeniach: ludzkość $(1,13 ; 17,2)$; jako kontrast do rzeczywistości ducha $(3,6 ; 6,63 ; 8,15)$ i w końcu w odniesieniu do ciała Jezusa $(1,14$; 6,51.52.53.54.55.56). Wszystkie miejsca z szóstego rozdziału mówią o konieczności spożywania ciała Jezusa, które jest wydane za życie świata w celu osiągnięcia życia wiecznego. Wyrażenie „ciało moje jest za życie świata” (sarks mou estin hyper tēs kosmou zōess) odnosi się do misterium męki i śmierci Jezusa, i należy do tych tekstów, które ściśle łączą Jezusowy fakt bycia człowiekiem w ciele z Jego śmiercią za grzechy ludzi. W całej Ewangelii Janowej takie spojrzenie na

25 M. Hengel, The Prologue of the Gospel of John, s. 271.

26 Zob. S. Mędala, Ewangelia według św. Jana, s. 271. 
cielesność faktu wcielenia Jezusa jest wyrażane także w prezentacji Jezusa jako Baranka Bożego, który „gładzi grzech świata” $(1,29)$; w obrazie Dobrego Pasterza, który „życie oddaje za owce” (10,51), w słowach Kajfasza o konieczności śmierci Jezusa, jako jednego człowieka za lud, „niżby miał zginać cały naród” $(11,50)$, które Ewangelista interpretuje jako proroctwo: „że Jezus miał umrzeć za naród, a nie tylko za naród, ale także, aby rozproszone dzieci Boże zgromadzić w jedno” 11,51-52) czy w słowach Jezusa: „Nikt nie ma większej miłości od tej, gdy ktoś życie swoje oddaje za przyjaciół swoich” $(15,13)$. Wszystkie te teksty pokazują, do jakiego stopnia słowo stało się ciałem, zarazem - w świetle tych tekstów - można powiedzieć, że w zdaniu „A Słowo stało się ciałem” zawarta jest już theologia crucis $^{27}$.

Nie ma już dzisiaj autora, albo jest ich bardzo niewielu, którzy podtrzymywaliby jeszcze twierdzenie Ernesta Käsemanna, że 1,14 reprezentuje „naiwny doketyzm", w którym wcielenie i męka są raczej mało ważne, a sam Jezus pokazuje się jako „dumny Bóg nad ziemią”, samo zaś wcielenie nie reprezentuje „kenozy, całkowitego wejścia w nasze człowieczeństwo" ${ }^{28}$. Cała Ewangelia Jana zaprzecza takiemu spojrzeniu. W danych Ewangelii rozbrzmiewa raczej Pawłowe rozumienie Jezusa z hymnu z Flp 2,3-5, czy z Rz 8,3. Jan mówi już wcześniej w Prologu o przyjściu Słowa, które jest określone jako światło $(1,9.11)$. Nie jest wykluczone, że owe przychodzenie Słowa odnosi się do czasów przed wcieleniem, w epoce Starego Testamentu, może jednak odnosić się także już do samego wcielenia. Przyjmując jedną lub drugą możliwość interpretacyjną, nic nie możemy powiedzieć o sposobie przyjścia Słowa. W 1,14 nie ma już miejsca na żadne niedomówienie ${ }^{29}$. Nikt lepiej w całym Nowym Testamencie nie oddał prawdy o wcieleniu Słowa. Ewangelia Janowa w wielu miejscach podkreśla człowieczeństwo Chrystusa: mówi o Jego pochodzeniu (1,45); przedstawia Go jako zmęczonego czy smutnego $(4,6.7 ; 19,28)$; mówi o Jego emocjach $(11,33)$; o płaczu (11,35); o lęku przed śmiercią $(12,27 ; 13,21)$; o ciele wydanym za życie świata $(6,51)$; w końcu nazywa Go człowiekiem $(8,40)^{30}$. Nie jest wykluczone, że mamy tutaj już do czynienia z polemiką z błędami doketyzmu (por. $1 \mathrm{~J}$ 4,2; 2 J 2,7) - jak podkreśla wielu badaczy - słusznie jednak zauważa S. Mędala:

Nie można jednak zacieśniać sensu w. 14 do jednostronnego akcentowania człowieczeństwa Jezusa w polemice z doketyzmem. Autor czwartej Ewangelii wykazu-

27 M. Hengel, The Prologue of the Gospel of John, s. 283.

28 E. Käsemann, Jezu letzter Wille nach Johannes 17,3 Aufl., s. 61n.98.145.158.

29 Tak już: J.H. Bernard, A Critical Commentary on the Gospel according to St. John, t. 1, s. 19.

30 Zob. S. Mędala, Chrystologia Ewangelii św. Jana, s. 85-86. 
je, że konkretne człowieczeństwo Jezusa i mało znaczące pochodzenie z Nazaretu, które w oczach Jego przeciwników jest podstawą do odrzucenia Jego roszczeń do synostwa Bożego jako bluźnierstwa, dla wierzącego jest miejscem objawienia się jedynego rodzaju istoty Bożej - Syna posłanego przez Ojca ${ }^{31}$.

W J 1,14 orzeczeniem jest aoryst egeneto, które jest także użyte w 1,3.10 na określenie dzieła stworzenia, którego Słowo jest pośrednikiem („wszystko przez nie się stało”); następnie w 1,5 na określenie pojawienia się Jana Chrzciciela („Stał się człowiek, posłany przez Boga, Jan mu było na imię”); w końcu na określenie działania Jezusa w 1,17: „łaska i prawda przez Jezusa Chrystusa stały się". We wszystkich tych przypadkach zostaje podkreślona historyczność konkretnego wydarzenia, pojawienie się czegoś lub kogoś na arenie historii. Sam czasownik gignomai wskazuje na zmianę w stosunku do uprzedniej sytuacji. Słowo, które do tej pory było w odwieczności Boga, a co zostało wyrażone za pomocą orzeczenia èn $(1,1.4 .9 .10)$ i którego działanie w całej ekonomii starotestamentalnej nie było - oczywiście jako działanie Logosu - oczywiste i bezpośrednio zauważalne (zauważalne było jako działanie Boga), staje się całkowicie namacalne, widzialne w historii. Sam odwieczny Bóg przychodzi jako istota ludzka. Jego wcielenie jest faktem, który się wydarzył w przeszłości (stąd aoryst). Orzeczenie egeneto w kontraście do stosowanego w odniesieniu do Logosu orzeczenia èn wskazuje na inny niż dotąd jego sposób istnienia. Jest to sposób: „nacechowany kruchością i słabością, właściwy człowiekowi. Nie przestaje «być u Boga», ale w pewnym momencie staje się obecne w świecie ludzkiej historii i zaczyna prowadzić prawdziwie ludzkie «historyczne» życie" ${ }^{32}$, aż do męki i śmierci na krzyżu, gdzie zostaje objawione w pełni, co znaczy, że „Słowo stało się ciałem”. Ma rację H. Witczyk, że „Między «ciałem» a «Słowem» istnieje ogromny dystans, porównywalny do tego między niebem i ziemia”, który został pokonany przez „Słowo, które stało się ciałem”33.

\section{2. „I zamieszkało między nami”}

Jan następnie mówi: kai eskēnōsen en hēmin („I zamieszkało między nami”). Y. Simoens zauważa, że tłumaczenie greckiego wyrażenia en hymin jako „między nami” nie jest do końca właściwe, ponieważ nie oddaje idei mocy oddziaływania wcielenia na wierzącego ${ }^{34}$. Użycie jednak przyimka en w J usprawie-

31 Idem, Ewangelia według św. Jana, t. I, s. 273.

32 H. Witczyk, Kościół Syna Bożego, s. 153.

33 Tamże, s. 154.

34 Y. Simoens, Secondo Giovanni, s. 136. 
dliwia tłumaczenie „między nami” (por. 10,19; 11,54). Usprawiedliwia to także kontekst zdania. Nie chodzi o to, aby podkreślić odziaływanie faktu wcielenia we wnętrzu wierzącego, ale o ukazanie jego fizycznej obecności, jako konsekwencji wcielenia. Należy zwrócić uwagę na formę orzeczenia. Jest nią aoryst. Chodzi zatem o konkretny fakt z przeszłości. Nie chodzi jednak autorowi o jakiekolwiek bycie czy zamieszkanie słowa. Tutaj dochodzi do głosu teologiczne spojrzenie na fakt bycia wcielonego słowa między ludźmi. Jan na określenie zamieszkania „Słowa, które stało się ciałem” używa czasownika skēnōo, który tłumaczy się jako „mieszkać w namiocie, rozbić namiot” i który oprócz tego miejsce jest użyty w NT jedynie w Ap 7,15; 21,3. Rdzeń skn, który znajduje się zarówno w czasowniku skēnoō, jak i w rzeczowniku skēnē („namiot”), przypomina hebrajski rdzeń škn („mieszkać, przebywać”), który znajduje się w rzeczowniku šekinah („miejsce spoczynku, mieszkanie) oraz miškan („mieszkanie”). Janowi raczej nie chodzi o to, aby określić tymczasowość czy stałość zamieszkiwania "Słowa, które stało się ciałem” między ludźmi. Czasownik skēnoō odsyła raczej do skēnē tou martyriou, tj. namiotu świadectwa czy namiotu spotkania (Wj 33.7.9; 40,2), w którym znajdowała się Arka Świadectwa, a który był miejscem obecności Boga pomiędzy ludem Izraela i który został potem zastąpiony przez świątynie. Było to miejsce dialogu Boga z człowiekiem. W teologii rabinackiej terminem technicznym na określenie obecności Boga pomiędzy swoim ludem był rzeczownik šekinah. Tłumaczenie aramejskie do Wj 25,8, gdzie mówi się w tekście hebrajskim: „Oni uczynią mi mikdāš [„przybytek”] i zamieszkam pomiędzy nimi”, brzmi: „)a sprawię zamieszkanie mojej šekinah pomiędzy nimi”. Šekinah, podobnie jak aramejskie memra („Słowo”), zastępuje samego Boga i w ten sposób zostaje jednocześnie uchroniona transcendencja Boga. W Targumie do Pwt 12,5 w sanktuarium zamieszkuje šekinah Boga zamiast Jego miłości. W Targumie do Oz 5,6 zagrożenie, że JHWH oddali się od swojego ludu, staje się oddaleniem się Jego šekinah ${ }^{35}$. Chociaż teksty te są późniejsze od Prologu, to jednak nie jest wykluczone, że zawierają one idee o wiele wcześniejsze i Jan patrzy na Jezusa Chrystusa jako šekinah Boga i to nie wcale w sensie, że ciało Jezusa staje się "namiotem” (nową świątynią) dla obecności Boga ${ }^{36}$, ale w tym sensie, że Jezus Chrystus jest samą obecnością Boga. Przybytek czy świątynia w ST były miejscem obecności Boga, ale zarazem chroniły Jego transcendencję, powodowały, że między Bogiem a ludźmi była pewna bariera czy dystans. W przypadku „Słowa, które stało się ciałem”

35 J.H. Bernard, A Critical and Exegetical Commentary [porównaj tytuł w bibliografii], s. 22; R.E. Brown, Giovanni, s. 46.

36 S. Mędala, Ewangelia według św. Jana, s. 273; H. Witczyk, Kościół Syna Bożego, s. $155-158$. 
chodzi o całkowite, bez żadnych barier i dystansu, wejście w historię, całkowite zniżenie się do ludzi. W słowach „i zamieszkało między nami” dostrzegam przykład teocentryzmu chrystologicznego w Czwartej Ewangelii, która - jak żadna inna Ewangelia - w wielu miejscach ukazuje Jezusa Chrystusa na równi z Bogiem Ojcem. Cały koncept, który proponuje nam autor nie jest jednak kalką ze ST. Wszystkie teksty, które mówią o obecności Boga jako šekinah w ST czy literaturze judaistycznej można traktować jedynie jako „zbliżenia do wcielenia się Boga". W Jezusie Chrystusie bariera między Bogiem a stworzeniem zostaje całkowicie zniwelowana.

Fakt „rozbicia namiotu” może być interpretowany także jako echo Syr 24,8, gdzie Mądrość rozbiła swój namiot [kataskēnōson] w Jakubie”, co dla niektórych badaczy obok analogii do tekstów z Mdr i Prz o uosobionej sophia (Mdr 7,24-27; Prz 8,22-31) jest przesłanką do przyjęcia tezy o tzw. chrystologii mądrościowej w Czwartej Ewangelii ${ }^{37}$.

Zamieszkanie wcielonego słowa jest „pomiędzy nami”. Kto kryje się pod zaimkiem hymin? Czy generalnie cała ludzkość? Odpowiedź na to pytanie jest ściśle związana z następną częścią wiersza, w którym następuje zmiana osób z trzeciej liczby pojedynczej na pierwszą liczby mnogiej: „oglądaliśmy Jego chwałę". Problem ten postaramy się rozwiązać w następnym paragrafie.

\section{3. „Oglądaliśmy Jego chwałę"}

C.S. Keener zauważa, że w różnych utworach starożytnych, pierwsza osoba liczby mnogiej zakłada, że narrator jest zaangażowany w działanie: „Zarówno historycy, jak i biografowie byli chętni do wspominania ich własnego spojrzenia na wydarzenie" 38 . Za wieloma interpretatorami uznaję, że Ewangelia Jana odzwierciedla tradycję naocznych świadków wydarzeń, do których należy także Jan (autor Ewangelii) ${ }^{39}$. Wydaje mi się, że van Houwelingen dostarczył wystarczających argumentów, aby podmiot domyślny „my” z całego wyrażenia

37 Na ten temat zob. B.III. Witherington, John's Wisdom: A Commentary on the Fourth Gospel, Louisville 1995; S.H. Ringe, Wisdom's Friends: Community and Christology in the Fourth Gospel; C.S. Keener, The Gospel of John: A Commentary, t. 1, s. 350-355.

38 C.S. Keener, „We beheld His Glory!” (John 1:14), w: John, Jesus, and History, v. 2: Aspects of Historicity in the Fourth Gospel, s. 15.

39 Istnieją różne próby interpretacji zaimka „my” z 1,14: my odnosi się do czytelników czy słuchaczy; my jest substytutem Ja autora (pluralis maiestaticus); „my” odnosi się do autora jako świadka oraz innych świadków; „My” odnosi się do autora $\mathrm{z}$ innymi wierzącymi i czytelnikami; w końcu do wspólnoty Janowej. Na temat różnych prób rozumienia „my” zob. P.H.R. van Houwelingen, John and the Others, s. 97. Zob. także R. Bauckham, Jesus and the Eyewitnesses, s. 358-383. 
odnieść do naocznych świadków życia Jezusa ${ }^{40}$. Ich świadectwa stały się źródłem dla opracowania całego materiału narracyjnego ${ }^{41}$, co zresztą jest zaznaczone bezpośrednio w Ewangelii w innych dwóch miejscach, na końcu dzieła: "Zaświadczył to ten, który widział, a świadectwo jego jest prawdziwe. On wie, że mówi prawdę, abyście i wy wierzyli” $(19,25)$ oraz „Ten właśnie uczeń daje świadectwo o tym i on to pisał, a wiemy, że świadectwo jego jest prawdziwe" $(21,24)$. Zatem podmiotem widzenia nie są „my wszyscy”, tj. wszyscy wierzący lub wszyscy czytelnicy czy słuchacze Ewangelii, ani cała wspólnota Janowa, ale ci, którzy spośród wierzących doświadczyli fizycznej obecności Jezusa (por. $1 \mathrm{~J} 1,1)$. Tak samo pod zaimkiem „my” w zdaniu: „i zamieszkało między nami” kryją się naoczni świadkowie ziemskiego życia Jezusa. Co nie oznacza, że słuchacze i czytelnicy nie mogą się odnaleźć w owym „my”. Oni dzięki świadectwu naocznych świadków, zapisanemu w Ewangelii, uwierzyli w Jezusa i tym samym pamięć o Jezusie (Ewangelia) staje się uobecniająca, dzięki czemu słuchacze i czytelnicy stają się także świadkami ${ }^{42}$.

Wracając do zdania „oglądaliśmy jego chwałę”, akcent pada na historyczność samego faktu widzenia, co podkreśla użyty w tym miejscu aoryst etheasametha („oglądaliśmy”). Konsekwencją wcielenia w przeszłości i jego zamieszkania między ludźmi, tj. jego fizycznej obecności, jest widzenie wcielonego Słowa. Sam czasownik theasthai jest używany w różnych miejscach w Corpus Johanneum: na określenie wizji Ducha zstępującego na Jezusa w czasie chrztu $(1,32)$, na oglądanie cudu wskrzeszenia Łazarza $(11,45)$. Spotykamy go także w 1 J, gdzie odnosi się do postrzegania Boga lub Chrystusa $(1,1 ; 4,12.14)$. Odnosi się także do widzenia samego Jezusa (J 1,35; 6,5). Szczególnie ważne są te miejsca, w których spotkamy pierwszą osobę liczby mnogiej: J 1,14; $1 \mathrm{~J} 1,1$; 4,14. Zgadzam się z R.E. Brownem, który twierdzi, że w Janie mamy różne typy wizji (Jan stosuje różne czasowniki na określenie widzenia: blepein, theasthai, theōrein, idein, horan). Na pewno używając różnych czasowników, Jan być może chce podkreślić specyficzny aspekt oglądania. Nie jest jednak w tym koherentny. Co do czasownika theasthai, może on odnosić się zarówno do prawdziwego fizycznego widzenia, jak i do kontemplowania w sensie oglądania czegoś i bycia cząstką tej rzeczywistości ${ }^{43}$. Nie chodzi jednak - jak chcą tego niektórzy

40 P.H.R. van Houwelingen, John and the Others, s. 95-115. Autor udowadnia, że pod my kryje się Jan (autor) jako „szef” świadków życia Jezusa wraz z samymi świadkami. Zob. także H. Witczyk, Kościół Syna Bożego, s. 157-158.

41 C.S. Keener, The Gospel of John, s. 81-115.

42 Określenie Ewangelii jako „pamięci o Jezusie” zaproponował G. Segalla, Teologia biblica del Nuovo Testamento (na temat czwartej Ewangelii zob. s. 477-506).

43 R.E. Brown, Giovanni, s. 1444. 
badacze - o jakieś „mistyczne spojrzenie na głębszą rzeczywistość” czy „duchowe oglądanie" ${ }^{44}$. W kontekście całego wiersza, w którym podkreśla się historyczność wydarzenia wcielenia („Słowo stało się”; „zamieszkało”) - wydaje mi się - że najlepszym tłumaczeniem jest zachowanie podstawowego znaczenia tego czasownika: „obserwować coś wyjątkowego” czy „oglądać z uwagą, zainteresowaniem, wnikliwością" ${ }^{35}$, co podkreślałoby realność widzenia, przy jednoczesnym podkreśleniu jego historyczności (aoryst wskazuje na definitywny moment w historycznej przeszłości). Miejsca w Corpus Johanneum, w których są zestawione obok siebie czasowniki widzenia horāō i theaomai $(1 \mathrm{~J} 1,1)$ reprezentują według mnie - $\mathrm{w}$ takim spojrzeniu nie jestem odosobniony - bardziej literacką wariację niż chęć podkreślenia różnicy znaczenia ${ }^{46}$, jak chcą tego badacze, którzy uważają, że pierwszy czasownik wskazuje na realne widzenie, drugi natomiast na kontemplowanie. Zatem autor skupia się bardziej na widzialności Słowa wcielonego i historycznym fakcie oglądania Go.

W wierszu tym nie mówi się o "oglądaniu Jezusa Chrystusa” (imię to pada dopiero na końcu Prologu), ale przedmiotem widzenia jest „chwała Jego”. Analizując rzeczownik doksa w Ewangelii wg św. Jana (J: 18 razy; Synoptycy: 23 razy) trudno byłoby go odnieść - jak chcą niektórzy badacze - do pojedynczego wydarzenia przemienienia Jezusa - jak to mamy u Synoptyków (por. Łk 9,32 ) - którego zresztą Jan nie relacjonuje ${ }^{47}$, ani tylko do wydarzeń po zmartwychwstaniu. Chodzi raczej o całą działalności Jezusa, która jest widziana w kluczu manifestacji „chwały Jego”. Taką manifestacją są znaki, tj. cuda Jezusa (por. pierwszy i ostatni znak w 2,$11 ; 11,4.40)$, misterium paschalne $(12,16.23$ -24; 13,31; 17,1.5) i połączone z nim zesłanie Ducha Świętego (por. 7,39; 19,30; $20,22)^{48}$. Dlaczego jednak Ewangelista nie mówi wprost o tych wydarzeniach, ale używa słowa „chwała”? Wydaje się, że mamy tutaj całkowicie świadomy zabieg, podobny do tego z poprzedniej części wiersza, gdzie mówi się o „rozbiciu namiotu”, polegającym na tym, że autor pragnie spojrzeć na historyczne wydarzenie, jakim było fizyczne doświadczenie obecności Jezusa, z perspektywy teologicznej. Całe wyrażenie „chwała Jego” powinna być interpretowana

44 Zob. wykaz autorów w: H. Thyen, Das Johannesevangelium, s. 95-97.

45 Por. J.P. Louw, E.A. Nida (ed.), Greek-English Lexicon of the New Testament Based on Semantic Domains, v. 2, s. 279.

46 Por. S.S. Smalley, 1,2,3 John, s. 8.

47 Po próby odpowiedzi na pytanie, dlaczego Jan nie relacjonuje w Ewangelii sceny przemienienia, odsyłam do: P.N. Anderson, The Riddles of the Fourth Gospel. An Introduction to John, s. 209nn.; P.H.R. van Houwelingen, John and the Others, s. $101 \mathrm{nn}$.

48 Błędem jest odnoszenie chwały tylko i wyłącznie do końca życia Jezusa: tak J.C. Meagher, John 1,14 and the New Temple, s. 62. 
w kontekście starotestamentalnego pojęcia kabod YHWH ( „chwały Boga”). Chwała Boga jest rozumiana jako widzialna manifestacja obecności Boga dla człowieka, szczególnie w aktach Jego potęgi (Lb 16,19; Ps 102,16; Ez 10,4). Bóg, będąc niewidzialny, manifestuje swoją obecność w konkretnych wydarzeniach, w historii. Kobod Boga uobecnia Jego działanie w historii. W ten sposób - jak zauważa E.R. Brown - kabod staje się - podobnie jak memra, šekinah - terminem zastępczym na określenie obecności Boga pośród swego ludu ${ }^{49}$. Odpowiednią odpowiedzią człowieka na takie objawienie jest oddanie chwały Bogu (Ps 22,23; 29,2; 86,9; Iz 66,5). W ST można zauważyć także związek pomiędzy chwałą Boga a Jego obecnością w Przybytku czy świątyni (Wj 40,34; 1 Krl 8,10-11; Ez 11,23; 44,4). Zatem w J 1,14 mamy do czynienia znowu ze spojrzeniem teologicznym na realną obecność słowa Wcielonego. Jezus, będąc wcielonym Słowem Boga, jest wcieleniem chwały Boga, tj. wcieleniem Jego obecności. To, co w Starym Testamencie odnosiło się do Boga w pojęciu „chwały” teraz odnosi się do Jezusa. Można zatem mówić o chrystologicznym spojrzeniu na „chwałę Boga” i wszystkie teksty, które mówią o chwale Boga w ST potraktować znowu jako „starotestamentalne zbliżenia do wcielenia się Boga”. Nie ulega wątpliwości, że takie spojrzenie na Jezusa jest przykładem tzw. „chrystologii wysokiej” czy innymi słowy, teocentryzmu chrystologicznego.

Oglądanie chwały Jezusa zostaje jednak w 1,14 doprecyzowane: „chwałą, jaką jednorodzony [ma] u Ojca”. Ważny jest tutaj termin monogenēs, który etymologicznie oznacza „jedyny w swoim rodzaju”. S. Mędala tłumaczy ten wyraz następująco: "pod względem pochodzenia stanowiący "jedność»" ten w LXX jest tłumaczeniem hebrajskiego słowa yāchid, „jedyny, najcenniejszy” (por. Rdz 22,2,12,16). Ta jedyność zasadza się na relacji do Ojca. Przyimek para w wyrażeniu para patros zakłada bezpośrednią relację obiektu („,jednorodzony") do źródła, którym jest Ojciec ${ }^{51}$. Można powiedzieć, że naoczni świadkowie w działalności Jezusa odkrywają tajemnicę Jego relacji do Ojca, tj. tajemnicę Jego bycia Synem Boga. Chodzi oczywiście o jedynego Boga Izraela (por. 5,44). Uznaje się, że termin synoptyczny agapētos („umiłowany”: Mk 1,11; 9,7; Mt 3,17; 17,5; Łk 3,22; 9,35) jest ekwiwalentny do monogenēs, ponieważ LXX za pomocą obydwu terminów tłumaczy hebrajskie słowo yāchid; jedno i drugie akcentuje jedyność i niepowtarzalność relacji Jezusa do Ojca ${ }^{52}$. Ta relacja, która zostanie potem ukazana w całej Ewangelii Janowej, stanowi dowód boskości Jezusa. Patrząc na życie Jezusa, naoczni świadkowie widzą Jego jedność z Ojcem

R.E. Brown, Giovanni, s. 47.

S. Mędala, Ewangelia według św. Jana, s. 275.

Tamże, s. 276.

Por. J.R. Michaels, The Gospel of John, s. 50. 
i dlatego autor może napisać, że „oglądaliśmy Jego chwałę”. Chwała Jezusa jest chwałą samego Boga, ponieważ Jezus i Ojciec są jedno. Można powiedzieć, że naoczni świadkowie we wcielonym Słowie doświadczają tego, o czym pisze Jan na początku Prologu „Słowo było skierowane ku Bogu i Bogiem było Słowo”. W całym tym zdaniu bardzo ważna jest partykuła hōs, która nie wskazuje tylko na wartość porównawczą, lecz może znaczyć także: „według”, „zgodnie z”, „na fundamencie czegos'"53. Jedyność relacji między Synem i Ojcem jest fundamentem chwały Jezusa.

W całym zdaniu „oglądaliśmy Jego chwałę, chwałę, jaką jednorodzony od Ojca [ma]" krzyżują się ze sobą historia i teologia. Autor koncentrując się na konkretnym wydarzeniu historycznym oglądania „wcielonego Słowa”, podaje jednocześnie jego głębsze znaczenie teologiczne, posługując się obrazami ze ST. Jego teologia jest nie do odłączenia od jego zainteresowania historycznym wydarzeniem, które nosi konkretne imię Jezusa Chrystusa.

Na końcu w. 14 znajdują się słowa: plērēs charitos kai alētheia. Do kogo odnosi się przymiotnik plērēs: do „Słowa” z początku wiersza, do „chwały” czy do „jednorodzonego" ${ }^{4}$. Forma (rodzaj męski liczby pojedynczej) wskazywałaby na pierwszą opcję. Nie jest jednak wykluczone, że plērēs ma wartość terminu abstrakcyjnego nieodmienialnego i można byłoby przetłumaczyć to słowo jako „pełnia”. Słowo wcielone jest „pełnią łaski i prawdy”. Należy jednak zauważyć, że wszystkie terminy, zarówno „Słowo”, „chwała”, jak i „jednorodzony” są związane z Jezusem Chrystusem. On jest „pełnią łaski i prawdy”.

Niektórzy badacze uważają, że mamy tutaj do czynienia z hendiadys i całe wyrażenie można byłoby przetłumaczyć jako „prawdziwa łaska, prawdziwe miłosierdzie, dar prawdy, wierna miłość" 55 . Taka sama kombinacja zostaje zastosowana w 1,17, gdzie „łaska i prawda” są przedstawione jako dary Jezusa dla ludzkości, w kontraście do Prawa, które zostało dane za pośrednictwem Mojżesza. Zwrócić trzeba jednak uwagę na istotną różnicę, która osłabia ten paralelizm. O Mojżeszu mówi się, że prawo „zostało dane” przez Niego (ho nomos dia Mōyseōs edothē), jest on tylko pośrednikiem w przekazie Prawa, o Jezusie natomiast Ewangelista mówi, używając tych samych sformułowań, które zastosował w opisie Jego roli w stworzeniu: „łaska i prawda przez Jezusa Chrystusa stały się" (hē charis kai hē alètheia dia Iēsou Christou egeneto).

53 Y. Simoens, Secondo Giovanni, s. 138.

54 Różne interpretacje wiersza w zależności do czego odniesie się termin plērēs podaje S. Mędala, Ewangelia według św. Jana, s. 276-277.

55 Zob. I. de la Potterie, La vérité dans saint Jean, s. 117-140; R.E. Brown, Giovanni, s. 20; S. Mędala, Ewangelia według św. Jana, s. 277. 
Wracając do wyrażenia „łaska i prawda”, w języku biblijnym charis (hbr. chesed) oznacza dobroć, łaskawość, współczucie, przysługę, otrzymaną dobroć. Ten termin spotykamy w Czwartej Ewangelii tylko w 1,14.16.17, natomiast dość często, bo aż 25 razy, występuje w dwudziele Łukaszowym (Łk-Dz). Rzeczownik alêtheia spotykamy bardzo często w Czwartej Ewangelii (J: 25 razy; Synoptycy: 7 razy; 1-3 J: 20 razy; NT: 109 razy), co wskazuje, że należy on do terminów preferowanych przez Ewangelistę i jest dla niego słowem kluczowym. Termin ten oznacza przede wszystkim objawienie przyniesione przez Jezusa Chrystusa. Zatem przez wyrażenie „pełnia łaski i prawdy” autor chce podkreślić, że w Jezusie Chrystusie koncentruje się i konkretyzuje się cała dobroć, łaskawość Boga oraz to, że w Nim jest obecna pełnia objawienia Boga jako Ojca.

„Łaska i prawda” są użyte w formie, która odzwierciedla starotestamentalną kopię chesed weemet, którą spotykamy chociażby w Wj 34,6-7 (por. Ps 25,10; $61,8 ; 86,15)$. Tekst ten można potraktować jako wyznanie wiary starożytnego Izraela ${ }^{56}$. Wj 34,6-7 jest częścią perykopy, którą rozpoczyna się w 34,5, a która należy traktować jako spełnienie prośby Mojżesza do Boga z 33,18: „Spraw, abym ujrzał Twoją chwałę". W 34,6-7 sam Bóg objawia tajemnicę swojej natury, której jednym $\mathrm{z}$ elementów jest wyrażenie rab-chesed wéemet. LXX tłumaczy słowo chesed przez eleos („miłosierdzie”) a nie przez charis, co mogłoby być argumentem przeciw widzeniu w J 1,14 aluzji do Wj 34,6-7. Należy jednak pamiętać, że Jan w Ewangelii, używając tekstów starotestamentalnych, nie jest zawsze wierny LXX, sam zaś termin charis - jak udowodnił już J.A. Montgomery - jest znakomitym tłumaczeniem hebrajskiego terminu chesed $^{57}$. Jan zatem atrybuty JHWH przypisuje samemu „Słowu, które stało się ciałem”. Nie ulega wątpliwości, że jest to kolejny przykład teocentryzmu chrystologicznego.

Objawienie nie jest czymś abstrakcyjnym. Jezus jako „pełnia łaski i prawdy", jako Bóg objawia się w konkretnej historii, stąd nie można stwierdzenia „pełnia łaski i prawdy” oddzielać od „oglądaliśmy Jego chwałę". C.S. Keener podkreśla, że widzenie bóstwa było jednym z kluczowych tematów greckiej i helleńsko-judaistycznej duchowości, w której mówi się o mistycznych wizjach (Filon z Aleksandrii) czy podkreśla się możliwość wizjonerskiego wstąpienia do nieba (literatura henochijska i apokaliptyka) ${ }^{58}$. Nie chodzi jednak tam o realne widzenie Boga. Na tym tle - jak słusznie zauważa S. Mędala:

56 D. Kotecki, „On Bogiem wiernym a nie zwodniczym” (Pwt 32,4), s. 15.

57 J.A. Montgomery, Hebrew Hesed and Greek Charis, s. 97-102. Zob. także R.E. Brown, Giovanni, s. 21.

58 Zob. C.S. Keener, „We beheld His Glory!”, s. 18-20. 
prolog głosi, że Bóg był rzeczywiście obecny w świecie, w Jezusie Chrystusie, i że to Słowo w ciele, tego prawdziwego Boga i prawdziwego człowieka wielu oglądało, wielu widziało Jego chwałę, widziało Go takim, jakim On jest. To nie człowiek wstąpił do Boga, ale Bóg przyszedł do człowieka z całą swą mocą i z całym swym majestatem ${ }^{59}$.

Naoczni świadkowie działalności Jezusa doświadczyli w swoim życiu teofanii, ale nie takiej, jakiej doświadczył Mojżesz, który mógł zobaczyć Boga tylko z tyłu, aby nie umrzeć (por. Wj 35,20.23), czy mistycznej wizji, której warunkiem było wstąpienie do nieba. Dla Jana całe teologiczne spojrzenie na Jezusa jest zakorzenione w Jego historycznej misji. „Historyczna substancja - jak podkreśla C.S. Keener - jest centralna dla jego [Jana] teologicznej perspektywy. Jego teologia jest nierozłączna od jego zainteresowania historycznymi wydarzeniami dotyczącymi Jezusa" ${ }^{\circ 0}$.

\section{Perspektywa teologiczno-historyczna i jej konsekwencje dla chrystologii}

W Jezusie wypełnia się to wszystko, co było zapowiedziane w obrazie szekinah, w oglądaniu chwały przez Mojżesza w Starym Testamencie. Te dwa obrazy można uznać za „starotestamentalne zbliżenia do wcielenia się Boga”. Dotychczasowa analiza J 1,14 może nas prowadzić do wniosku, że na dane chrystologiczne patrzy się w kluczu tekstów, które w ST odnoszą się do Boga. Mielibyśmy zatem w J 1,14 przykład chrystologii teocentrycznej, czy teologii chrystocentrycznej, czego znakomitym przykładem może być także Apokalipsa św. Jana ${ }^{61}$. Na pewno mamy tutaj do czynienia z tzw. chrystologię wysoką lub boską, która zostanie zilustrowana w całej Ewangelii, a której dane zgadzają się z chrystologią najstarszych świadków wiary chrześcijańskiej reprezentowanych chociażby przez św. Pawła. Źródła tej chrystologii należy szukać w tajemnicy Jezusa, która jest tajemnicą relacji Syna do Ojca. W J 1,14 chrystologia opowiedziana jest cała zakorzeniona w Starym Testamencie i jest przygotowana przez Stary Testament. Patrząc z perspektywy J 1,14 na Stary Testament można powiedzieć, że zawiera on chrystologię ukrytą, co w późniejszym okresie zostało sformułowane jako zasada hermeneutyczna przez św. Augustyna i przy-

\footnotetext{
59 S. Mędala, Ewangelia wedtug św. Jana, s. 283.

60 C.S. Keener, „We beheld His Glory!”, s. 15.

61 Na ten temat zob. D. Kotecki, Jezus a Bóg Izraela w Apokalipsie św. Jana. W ten sposób znajdujemy jeszcze jedną przesłankę, aby uznać jedność teologiczną Pism Janowych.
} 
pomniana w konstytucji Dei Verbum Soboru Watykańskiego II: „Bóg sprawca natchnienia i autor ksiąg obydwu Testamentów, mądrze postanowił, by Nowy Testament był ukryty w Starym, a Stary Testament w Nowym znalazł swe wyjaśnienie" (KO 16). Jednocześnie jednak ta chrystologia jest zakorzeniona w konkretnej historii, historyczna substancja - jak już to zostało powiedziane - którą jest życie i działalność konkretnego człowieka, Jezusa z Nazaretu, stanowi fundament dla tej chrystologii. J 1,14 jest przykładem spotkania się historii i teologii. W starożytności chrześcijańskiej na interpretację Czwartej Ewangelii wielki wpływ miało stwierdzenie Klemensa Aleksandryjskiego, przytoczone przez Euzebiusza z Cezarei, że ta Ewangelia ma przede wszystkim charakter duchowy i uwydatnia przede wszystkim bóstwo Jezusa ${ }^{62}$. W egzegezie starożytnej szkoła antiocheńska kładła nacisk na bóstwo Jezusa, szkoła aleksandryjska akcentowała człowieczeństwo Jezusa. Pierwsza przygotowała herezję doketyzmu, druga adopcjonistyczne rozumienie osoby Jezusa ${ }^{63}$. W J 1,14 łączą się ze sobą spojrzenia na Chrystusa jako na Boga (Logos) i człowieka, zakorzenionego w konkretnej historii (użyte $\mathrm{w}$ jednym zdaniu trzy aorysty: egeneto, eskēneusen, etheasametha, podkreślają, że wydarzenie wcielenia z całymi jego konsekwencjami, było faktem, który się wydarzył w przeszłości). Jednocześnie jednak, użycie słów przywołujących wydarzenia ze Starego Testamentu („rozbiło namiot”, „oglądaliśmy Jego chwałę”, „pełnia łaski i prawdy”), pokazują, że Ewangelista patrzy na te konkretne wydarzenia z perspektywy teologicznej. Ewangelista nie tylko interesuje się zatem wydarzeniami, lecz także ich teologiczną interpretacją. J 1,14 staje się w ten sposób kluczem czy paradygmatem do interpretacji całej Ewangelii, zwłaszcza jej chrystologii, która nie może być ani jednostronnie historyczna, ani jednostronnie teologiczna. Ten jeden wiersz potwierdza to, o czym mówią niemal wszyscy badacze, że Ewangelie są narracjami, które bazują na historii, ale są jednocześnie narracjami teologicznymi.

Czy Jan w swoim spojrzeniu jest całkowicie oryginalny? W J 1,1-2 ewangelista prezentuje tożsamość Chrystusa, sięgając do początku, którym jest świat Boga. Ta sama perspektywa otwiera zdanie: „A Słowo stało się ciałem”. Nie mogę zgodzić się całkowicie z H. Witczykiem, który zauważa, że prologi w pozostałych ewangeliach mają charakter historyczny, a tylko Prolog Jana „sięga w prezentacji do początku, którym jest świat Boga" ${ }^{64}$. Podobny charakter ma Prolog do Ewangelii wg św. Marka (1,1-13). Nie ulega wątpliwości - nawet przyjmując tezę o pochodzeniu J z odrębnego nurtu tradycji - że najwięcej po-

\footnotetext{
62 Euzebiusz, Historia Kościelna, 6,14,7. 
dobieństw występuje miedzy J a Ewangelią wg św. Marka ${ }^{65}$. Wracając do prologu w Ewangelii wg św. Marka (1,1-13), tam od razu po tytule dzieła; „Początek Ewangelii o Jezusie, Mesjaszu, Synu Bożym" $(1,1)$ mamy odniesienie do słów ze Starego Testamentu: „Jak jest napisane u proroka Izajasza: «Oto posyłam anioła mojego przed tobą, ten przygotuje drogę przed tobą. Głos wołającego na pustyni: Przygotujcie drogę Panu, prostujcie dla Niego ścieżki»" (1,2-3). Początek cytowanego przez Marka dyskursu Boga, który na pewno nie pochodzi z Iz, jest skierowany do jakiegoś „ty” („przed tobą”). W dyskursie tym wielu badaczy doszukuje się aluzji do Wj 23,20, gdzie czytamy: „Oto ja poślę mojego wysłańca przed Tobą”. Jest to wyrocznia skierowana do Izraela, któremu Bóg obiecuje swojego posłańca, który poprowadzi lud do ziemi Kanaan. Z całego kontekstu jednak wynika, że tekst Markowy jest bardziej przyporządkowany Ml 3,1 („Oto ja poślę wysłannika mego, aby przygotował drogę przede Mną”), w którym Bóg zapowiada swoje przybycie w „dzień Pański”. Wyjątkowość przyjścia „kogoš” w Mk ukazuje się w tym, że będzie ono poprzedzone pojawieniem się wysłańca Bożego (angelos mou), podobnie, jak w przypadku przyjścia samego YHWH. Zostaje w ten sposób doprecyzowane, kim jest ten, który przyjdzie. Tylko przyjście Boga było poprzedzane pojawieniem się wysłańca. Owe „ty” przynależy do świata Boga. Staje się to jeszcze bardziej widoczne w drugiej cytacji, pochodzącej z Iz 40,3. Miedzy tymi dwoma cytatami zachodzi ścisły paralelizm: „droga twoja” (hodos sou) z 1,2 jest „drogą Pana” (hodos kyriu) z 1,3. W tekście masoreckim głos krzyczy: „Na pustyni przygotujcie drogę dla YHWH. Wyprostujcie na pustkowiu ścieżkę dla naszego Boga". W LXX słowo kyrios zastępuje imię samego Boga. Spełnieniem zapowiedzi pojawienia się posłańca jest przyjście Jana Chrzciciela, który głosi przyjście „silniejszego od niego”, czyli tego, dla którego drogę miał przygotować. Tym kimś jest Jezus Chrystus, który wchodzi na scenę historii (tutaj dopiero możemy mówić o charakterze historycznym) w 1,9: „Przyszedł Jezus z Nazaretu w Galilei”. Jezus z Nazaretu jest owym „ty” z Mk 1,2, który istniał w świecie Boga, podobnie jak Logos z J, chociaż Marek nie nadaje mu jakiegoś specjalnego imienia, jedynie aplikuje do niego teksty starotestamentowe, które używają Bożego imienia ${ }^{66}$. „To imię nie odnosi się

65 Wystarczy porównać perykopy: o działalności Jana Chrzciciela: Mk 1,4-8, J 1,29-36; powrót Jezusa do Galilei: Mk 1,14, J 4,3; nakarmienie pięciu tysięcy: Mk 6,34-44, J 6,1-13; chodzenie Jezusa po wodzie: Mk 6,45-52, J 6,14-21; żądanie znaków: Mk 8,11, J 5,30; wyznanie Piotra: Mk 8,29, J 6,68; wyruszenie Jezusa do Jerozolimy: Mk 11,1-10, J 12,12-15; namaszczenie w Betanii: Mk 14,3-9, J 12,1-8; ostatnia wieczerza: Mk 14,17-26, J 13,1-17,26; pojmanie na Górze Oliwnej: Mk 14,43-52, J 18,1-12a; opis męki i zmartwychwstania: Mk 14,53-16,8, J 18,12b-20,29.

66 Por. D. Kotecki, Chrzest Jezusa w Ewangelii według św. Marka (1,9-11) a idea samouniżenia się Boga, s. 15-16. 
do boskich funkcji, ale do jedynej boskiej tożsamości. Ewangelista podkreśla w ten sposób, że Jezus uczestniczy w tej jedynej tożsamości samego Boga. [...]. Nie można jednak zapomnieć, że z cytowanego proroctwa wynika jasne rozróżnienie osób: Boga i Jezusa. Podmiotem wypowiedzi jest Bóg, adresatem zaś Jezus" ${ }^{\prime \prime}$. Prolog do Ewangelii wg św. Marka ma podobną perspektywę, co Pro$\log$ Janowy $^{68}$.

Wracając do Ewangelii Jana, cała działalność Jezusa, doświadczana przez naocznych świadków i streszczona w 1,14 prostym stwierdzeniem „oglądaliśmy Jego chwałę", musiała prowokować podstawowe pytanie chrystologiczne: kim On jest? To, co zostało zapisane w 1,14, jest próbą odkrycia tajemnicy tożsamości Tego, którego „ujrzały nasze oczy, na co patrzyliśmy, czego dotykały nasze ręce" (por. $1 \mathrm{~J}$ 1,1). Cała ziemska historia Jezusa - opisana w Czwartej Ewangelii - rozpoczyna się - podobnie jak w Ewangelii wg św. Marka - od wystąpienia Jana Chrzciciela, rozwija się następnie w „znakach”, dyskursach i kontrowersjach, królewskiej śmierci na krzyżu69, aby zakończyć się tryumfem w Jego zmartwychwstaniu i uroczystą proklamacją Tomasza: „Pan mój i Bóg mój” $(20,28)$. Można za G. Segallem powiedzieć: „Tajemnicze i enigmatyczne objawienia, znaki ciągle bardziej nadzwyczajne, dialogi i szorstkie kontrowersje wynikają z tożsamości Jezusa Chrystusa, Słowa wcielonego i Syna Bożego, co więcej theos $(1,1-2 ; 20,28)$ ". Początek Prologu oraz wyznanie Tomasza, jak klamrą spinają całą historię ziemską "Słowa, które stało się ciałem”. Historia krzyżuje się z teologią.

Odczytany z perspektywy historyczno-teologicznej J 1,14 pozwala uniknąć dwóch tendencji, które jawiły się w historii w odniesieniu do chrystologii Janowej: jednostronne wyakcentowanie człowieczeństwa Jezusa (wspominana już szkoła antiocheńska, adopcjonizm, Teodor z Mopswestii, Nestoriusz, współcześnie zaś Bultmann i jego naśladowcy) lub jednostronne wyakcentowanie bóstwa Jezusa (wspomniana już szkoła aleksandryjska, doketyzm, współcześnie zaś Lütgert, Käsemann, Schulz, Schottroff i inni) ${ }^{70}$. Te dwie tendencje są w moim przekonaniu - skutkiem oddzielenia historii i teologii. W chrystologii

67 Tamże.

68 Zob. J. Beutler, Il Vangelo di Giovanni. Commentario (tłumaczenie włoskie z oryginału niemieckiego). Autor prezentuje czwartą Ewangelię jako świadectwo I w. chrześcijaństwa, która bazuje jako na swoich źródłach na Pismach Izraela oraz na starożytnej tradycji chrześcijańskiej, zwłaszcza na ewangeliach synoptycznych.

69 Męka i śmierć Jezusa jest widziana przez Jana, jako triumf królewskiej godności Jezusa jako Mesjasza. W rozdziałach opisujących mękę i śmierć (J 18-19) znajdujemy aż 12 razy użyty termin basileus („król”).

70 Pisał na ten temat S. Mędala, Chrystologia Ewangelii św. Jana, s. 80-85. 
współczesnej mówi się o tzw. chrystologiach oddolnych, które uznają za jedyny możliwy punkt wyjścia człowieczeństwo Chrystusa. Wyróżnia się dwa typy tej chrystologii: antropologiczny i historyczny. Pierwszy i drugi znakomicie streścił G. Strzelczyk. W pierwszym typie:

punktem wyjścia jest pewna koncepcja człowieka, zgonie z którą jest on z natury otwarty na zjednoczenie z Bogiem, co więcej - zjednoczenie to jest konieczne do pełnej realizacji człowieczeństwa. Owo zjednoczenie konkretnie w historii dokonuje się tylko raz: w Jezusie Chrystusie, jednak ma znaczenie dla człowieczeństwa jako takiego ${ }^{71}$.

W tej koncepcji problematyczne jest ukazanie boskości jako elementu koniecznego do spełnienia ludzkiej natury. Jak zauważa Strzelczyk: „Trywializując nieco, bycie Bogiem jest naturalnym przeznaczeniem człowieka, a więc to, że pojawia się taki człowiek, który jest Bogiem, jest tylko kwestią czasu"72. Punktem wyjścia dla drugiego typu chrystologii jest historyczna postać Jezusa, stąd bardzo ważnymi są badania nad historycznym Jezusem. Strzelczyk podkreśla, że te chrystologie wyrzekają się idei wcielenia, jako „wybitnie „odgórnej” i w konsekwencji:

Klasyczne twierdzenie o boskości Jezusa reinterpretują w kategoriach symbolicznych lub paradygmatycznych - Jezus jest Bogiem w tym sensie, że w Jego życiu i śmierci symbolicznie ujawniało się powszechnie i nieustannie działanie zbawcze Boga, albo że Jego życie i śmierć stanowią uniwersalnie aktualny model związku człowieka z Bogiem. [...]. W efekcie postać Jezusa zostaje zrelatywizowana: obok Niego można sobie wyobrazić inne postacie historyczne, sprawujące podobną, symboliczną czy paradygmatyczną rolę ${ }^{73}$.

Cały Prolog pokazuje, że chrystologię należy budować od góry, co wcale nie wyklucza wyeliminowania danych, które pochodzą z refleksji nad historią Jezusa z Nazaretu. On ma konkretną swoją historię i w tej historii jest zakorzeniony (jeszcze raz należy przypomnieć użycie aorystów w studiowanym przez nas wierszu). J 1,14 mówi o „Słowie, które stało się ciałem”, a nie o „ciele, które stało się Słowem”. W wierszach poprzedzających bezpośrednie stwierdzenie o wcieleniu Słowa, opisuje się boską egzystencje i działanie Słowa w historii. Zostaje ukazany w ten sposób właściwy kierunek badań chrystologicznych. Chrystolo-

71 G. Strzelczyk, Teraz Jezus. Na tropach żywej chrystologii, s. 99-100.

72 Tamże, s. 100.

73 Tamże, s. 101. 
gia odgórna staje się punktem wyjścia, a nie dojścia całej chrystologii. Trafnie zauważa to kardynał Ch. Schönborn:

Jeżeli bowiem wychodzi się z założenia, że trzeba traktować Jezusa najpierw jako człowieka, a dopiero potem pytać się: Czy ten oto człowiek jest Synem Bożym i Bogiem? - wówczas nie dojdzie się nigdy do jakiejkolwiek pozytywnej odpowiedzi. Chrystologia, która tak te rzeczy ujmuje, nie jest w stanie sięgnąć ponad wymiar profetyczny. Jezus może jej się jawić wyłącznie jako człowiek, który jest rzecznikiem Boga, ale nie jako Bóg Wcielony. Powinniśmy przeto traktować Wcielenie jako pra-daną chrystologii, co oznacza konkretnie, że powinniśmy zawsze rozważać życie i Osobę Jezusa jako Boga Wcielonego. Dopiero potem trzeba będzie uzasadnić to ujęcie. Cała moc chrześcijańskiego wyznania wiary opiera się na tym, że ten właśnie człowiek był i jest prawdziwie Synem Bożym (Mk 15,39), nie tylko reprezentantem Boga, ale samym Bogiem, Synem Bożym, który stał się człowiekiem. Cała siła wiary chrześcijańskiej polega tez na tym, że On, który żył ubogo w Galilei, łaknął i odczuwał pragnienie, jest naprawdę Bogiem ${ }^{74}$.

Podsumowując, w zdaniu J 1,14, ukazującym tajemnicę Jezusa Chrystusa, krzyżują się ze sobą teologia i historia. Chociaż punktem wyjścia tej chrystologii jest sięgnięcie do świata Boga (Logos) to jednak nie można nie docenić konkretnego człowieczeństwa Jezusa. Logos „stał się ciałem” w konkretnym momencie historii. Chrystus nie jest ahistoryczny. Właściwie odczytane zdanie: „A Słowo stało się ciałem i zamieszkało miedzy nami, i oglądaliśmy Jego chwałę, chwałę, jaką jednorodzony ma od Ojca, pełnia łaski i prawdy" przywraca równowagę między chrystologią odgórną i oddolną ${ }^{75}$, poprzez wskazanie, że chrystologia nie może być jednostronnie historyczna, czy jednostronnie teologiczna, że chrystologia jest zakorzeniona w Pismach Żydów - w Starym Testamencie, który zawiera chrystologię ukrytą („starotestamentalne zbliżenia do wcielenia) pozwalającą odkryć, że sam Chrystus jest Teologią. 


\section{Bibliografia}

Anderson, P.N., The Riddles of the Fourth Gospel. An Introduction to John, Minneapolis 2011.

Bauckham, R., Jesus and the Eyewitnesses. The Gospels as Eyewitness Testimony, Grand Rapids-Cambridge 2006.

Bernard, J.H., A Critical Commentary on the Gospel according to St. John, t. 1, Edinburgh 1928.

Beutler, J., Il Vangelo di Giovanni. Commentario, Analecta Biblica - Studia 8, Roma 2016 (tłumaczenie włoskie z oryginału niemieckiego).

Brown, R.E., Giovanni. Commento al Vangelo spirituale, Assisi 1991, s. 1467-1471 (tłumaczenie włoskie $\mathrm{z}$ oryginału angielskiego).

de la Potterie, I., La vérité dans saint Jean, AnBib 73. Roma 1977.

Breviarium Fidei. Wybór doktrynalnych wypowiedzi Kościoła, opr. S. Głowa - I. Bieda, Poznań 1988.

Hengel, M., Studies in Early Christology, Edinburgh 1995 (tłumaczenie angielskie z oryginału niemieckiego).

Hengel, M., The Prologue of the Gospel of John as the Gateway to Christological Truth, w: The Gospel of John and Christian Theology, ed. R. Bauchham, C. Mosser, Grand Rapids-Cambridge 2008, s. 265-294.

Käsemann, E., Jezu letzter Wille nach Johannes 17,3 Aufl., Tübingen 1971.

Keener, C.S., Komentarz historyczno-kulturowy do Nowego Testamentu, Warszawa 2000 (tłumaczenie polskie z oryginału angielskiego).

Keener, C.S., The Gospel of John: A Commentary, t. 1, Peabody 2003, 350-355.

Keener, C.S., „We beheld His Glory!” (John 1:14), w: John, Jesus, and History, v. 2: Aspects of Historicity in the Fourth Gospel, ed. P.N. Anderson, F. Just, T. Thatcher, Atlanta 2009, s. 15-25.

Kotecki, D., „On Bogiem wiernym a nie zwodniczym” (Pwt 32,4). Refleksja biblijno-teologiczna nad wiernością Boga w Starym Testamencie, CT 75 (2005), n. 2, s. 13-38.

Kotecki, D., Chrzest Jezusa w Ewangelii według św. Marka (1,9-11) a idea samouniżenia się Boga. Przyczynek do chrystologii drugiej Ewangelii, Teologia i Człowiek 20 (2012), s. 9-26.

Kotecki, D., Jezus a Bóg Izraela w Apokalipsie św. Jana, Scripta Theologica Thoruniensia 27, Toruń 2013.

Louw, J.P.- Nida, E.A. (ed.), Greek-English Lexicon of the New Testament Based on Semantic Domains, v. 2, Cape Town 1989.

Meagher, J.C., John 1,14 and the New Temple, JBL 88 (1969) n. 1, s. 58-68.

Mędala, S., Chrystologia Ewangelii św. Jana, Kraków 1993.

Mędala, S., Ewangelia według świętego Jana, rozdziały 1-12. Wstęp, przekład z oryginału, komentarz, NKBNT IV/1, Częstochowa 2008.

Michaels, J.R., The Gospel of John, NICNT, Grand Rapids-Cambridge 2010.

Montgomery, J.A., Hebrew Hesed and Greek Charis, HTR 32 (1939), s. 97-102. 
Ringe, S.H., Wisdom's Friends: Community and Christology in the Fourth Gospel, Louisville 1999.

Rochais, G., La Formation du Prologue (Jn 1:1-18), Science et espirit 37 (1985), s. 5-44.

Segalla, G., Teologia biblica del Nuovo Testamento. Tra memoria escatologica di Gesù e promessa del futuro regno di Dio, Torino 2005.

Simoens, Y., Secondo Giovanni. Una traduzione e un'interpretazione, Bologna 1998 (tłumaczenie włoskie z oryginału francuskiego).

Schönborn, Ch., Bóg zesłał Syna Swego. Chrystologia, AMATECA Podręczniki teologii katolickiej 7, Poznań 2002 (tłumaczenie polskie z oryginału niemieckiego).

Smalley, S.S., 1,2,3 John, WBC 51, Nashville-Dallas-Mexico City-Rio de Janeiro-Beijing 2007.

Thyen, H., Aus der Literatur zum Johannesevangelium, TR 39 (1975), s. 53-69; 222-252.

Thyen, H., Das Johannesevangelium, HNT, Tübingen 2005,

Tobin, T., The Prologue of John and Hellenistic Jewish Speculation, CBQ 52 (1990), s. $252-269$

van Houwelingen, P.H.R., John and the Others: To Whom Does the „We” in Fourth Gospel's Prologue and Epilogue Refer?, Fides Reformata 19 (2014), n. 2, s. 95-115.

van Wahlde, U.C., The Gospel and Letters of John, v. 2: Commentary on the Gospel of John, Grand Rapids-Cambridge 2010.

Witczyk, H., Kościół Syna Bożego. Studium eklezjologii Czwartej Ewangelii, Biblioteka „Verbum Vitae” 3, Kielce 2012.

Witherington, B.III, John's Wisdom: A Commentary on the Fourth Gospel, Louisville 1995. 